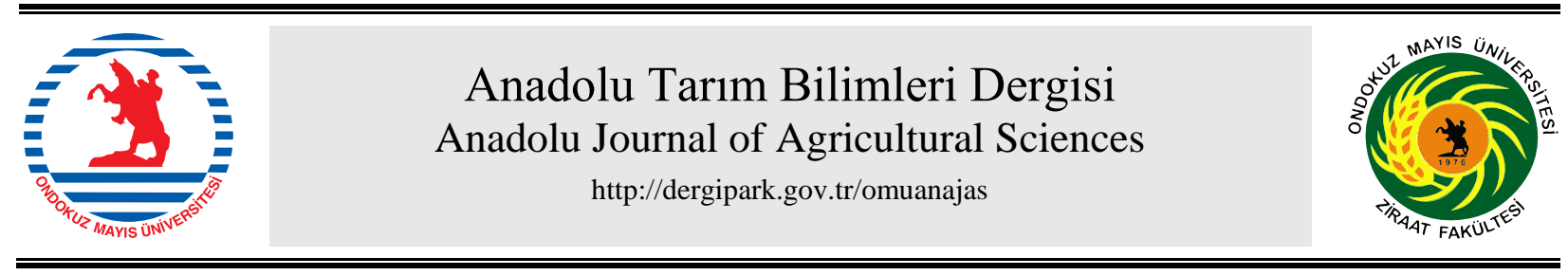

\title{
Araştırma/Research
}

Anadolu Tarım Bilim. Derg./Anadolu J Agr Sci, 34 (2019)

ISSN: 1308-8750 (Print) 1308-8769 (Online) doi: $10.7161 /$ omuanajas.557601

\section{Toprakların tuzluluk ve sodikliliğinin alansal ve zamansal değişiminin jeoistatistiksel yöntemlerle değerlendirilmesi: Bafra ovası örneği}

\author{
Sevda Taşan*, Yusuf Demir \\ ${ }^{a}$ Ondokuz Mayıs Üniversitesi, Ziraat Fakültesi, Tarımsal Yapılar ve Sulama Bölümü, Samsun \\ *Sorumlu yazar/corresponding author: sevda.safi@omu.edu.tr
}

Geliş/Received 24/04/2019 Kabul/Accepted 30/09/2019

\begin{abstract}
ÖZET
Sulu tarım alanlarında uygun sulama yönetiminin seçimi ve sulama suyu kalitesine bağlı olarak tuzlulaşma problemleri ile drenajın yönetimi sürdürülebilirliği etkileyen önemli faktörlerdir. Toprak tuzluluğu ve sodiklik sulanan tarım alanlarındaki bitki üretimini sınırlayan iki önemli özelliktir. Bu özelliklerin alansal ve zamansal değişimlerinin bilinmesi bitki gelişimindeki negatif etkilerini engellemek için önemlidir. Bu çalışma 2010 ve 2016 yıllarında Bafra ovası sağ sahil topraklarındaki tuzluluk ve sodikliğin alansal değişimlerinin belirlenmesi ve sulamanın toprak tuzluluğu ve sodikliği üzerine etkisinin değerlendirilmesi amacıyla yapılmıştır. Çalışma alanından 2010 ve 2016 yıllarında dört derinlikten bozulmuş toprak örnekleri alınmıştır. Toprakların tekstür, elektriksel iletkenlik (EC), toprak reaksiyonu $(\mathrm{pH})$, değișebilir sodyum yüzdesi (ESP) ve $\mathrm{CaCO}_{3}$ içerikleri laboratuvar analizleri ile belirlenmiştir. Toprak özelliklerinin alansal bağımlılı̆̆ını belirlemek için deneysel semivariogramlar geliştirilmiş ve örneklenmemiş noktalardaki özellikleri tahmin etmek için ordinary kriging analizi yapılmıştır. Toprakların EC ve ESP değerleri tüm derinliklerde ve tüm dönemlerde yüksek değişkenlik ve orta derecede alansal bağımlılık göstermiştir. Çalışma alanında en düşük değişkenliğin pH parametresinde olduğu görülmüştür. Çalışma alanı topraklarının tekstür içeriklerinin yüksek değişkenlik gösterdiği belirlenmiştir. Tüm değişkenlerin jeoistatistiksel etki uzaklığı 3100 m'den büyük bulunmuştur. Ayrıca toprakların EC ve ESP'sinin alansal dağılımı 2010 yılından 2016 yılına kadar önemli derecede azalmıştır. Bunun nedeni ise topraktaki tuzların yıkanarak drenaj sistemi yardımıyla araziden uzaklaştırılmasına bağlanmıştır. Çalışma alanının doğusunda tuzluluğun yüksek olduğu alanlar ile sodik alanların varlığı belirlenmiștir. Bu durum ise bu alanlarda yeraltı suyu seviyesinin yüksek olmasına bağlanmıştır. $\mathrm{Bu}$ alanlarda sulama mevsiminde buharlaşma ile çözünebilir tuzların yukarı taşınmasının takibi için yeraltı suyu tuzluluğu ve derinliğinin düzenli olarak izlenmesi önerilmiştir. Özelliklerin alansal dağılım haritaları incelendiğinde tuzluluk ve sodiklik değişkenlerinin yönetimi ile ilgili uygulamaların daha çok doğu-batı yönünde planlanmasının yararlı olacağı düşünülmektedir.
\end{abstract}

Evaluation of spatial and temporal changes of soil salinity and sodicity using geostatistic methods: the case of Bafra plain

\section{ABSTRACT}

Selection of appropriate irrigation management in irrigated agricultural areas and drainage management with salinization problems depending on the quality of irrigation water are important factors affecting sustainability. Soil salinity and sodicity are two important features that limit plant production in irrigated agricultural areas. It is important to know the spatial and temporal changes of these properties in order to prevent negative effects on plant development. This study was carried out to determine the spatial changes of salinity and sodicity and to evaluate the effect of irrigation on soil salinity and sodicity in the right coastal areas of Bafra plain in 2010 and 2016. Soil samples were taken from the study area with four different depth in 2010 and 2016. Soil texture, electrical conductivity (EC), soil reaction $(\mathrm{pH})$, exchangeable sodium percentage (ESP) and $\mathrm{CaCO}_{3}$ contents were determined by laboratory analysis. In order to determine the spatial dependence of soil properties, experimental semivariograms were developed and ordinary kriging analysis was performed to estimate the properties at non-sampled points. The EC and ESP values of the soils showed high variability and moderately spatial dependence at all depths and in all periods. The lowest variability was observed in the $\mathrm{pH}$

Anahtar Sözcükler:

Bafra ovas1

Coğrafi Bilgi

Sistemleri

Jeoistatistik

Sodiklik

Tuzluluk
Keywords: Bafra plain Geographical Information Systems Geostatistics Sodicity Salinity 
parameter in the study area. Texture contents of the study area soils showed high variability. Geostatistical range values of all variables was found to be greater than $3100 \mathrm{~m}$. Furthermore, the spatial distribution of the EC and ESP of soils has decreased significantly from 2010 to 2016. The reason for this is due to the removal of the salts in the soil from the field by means of the drainage system. High salinity areas and the presence of sodic areas were determined at the east of the study area. This is due to the high groundwater level in these areas. Monitoring of groundwater salinity and depth has been proposed regularly in order to follow the uptake of soluble salts by evaporation during irrigation season in these areas. When the spatial distribution maps of the properties are examined, it is considered that it would be beneficial to plan the applications related to salinity and sodicity variables in the east-west direction.

\section{Giriş}

Toprak ve su kaynaklarının etkin kullanımı ve sürdürülebilir yönetiminin önemi gittikçe artmaktadır. Ülkemizin sahip olduğu su kaynakları sınırlı olup, en iyi şekilde kullanılması büyük önem taşımaktadır. Toprak tuzluluğu ve sodikliği özellikle kurak ve yarı kurak alanlarda bitkisel üretim üzerinde olumsuz bir etkiye sahip olan önemli kimyasal özelliklerdir (Malicki ve Walczak, 1999; Ahmad ve ark., 2011; Moasheri ve Foroughifar, 2013; Elbashier et al. 2016). Tuzluluk ve sodiklik dünya çapındaki toprak bozulmasını kötüleştiren en önemli iki nedendir ( $\mathrm{Li}$ ve ark., 2015; Wichelns ve Qadir 2015; Dinh ve ark., 2018). Birleşmiş Milletler Gıda ve Tarım Örgütü (FAO)'ne göre dünya çapındaki arazilerin \% 6'sından fazlası ya tuzluluk ya da sodiklikten etkilenmektedir (Dai ve ark., 2014; Joseph, 2016). Ayrıca çeşitli nedenlerden dolayı tuzlanan alanlar yıllık \% 10 oranında artmaktadır. Tarımsal üretimde tuzlu su kullanımı bu artıșın başlıca nedenlerinden bir olarak kabul edilmektedir (Dinh ve ark., 2018). Tuzlu topraklar yükssek oranda suda çözünür tuzlar içerir ve genellikle toprak elektriksel iletkenliği (EC) yoluyla değerlendirilmektedir. EC değeri $4 \mathrm{dS} \mathrm{m}$ ${ }^{1}$,den büyük ise tuzlu toprak olarak kabul edilir. Yapılan çalışmalar toprakta EC'nin toprak tuzluluğunu izlemek için güvenilir bir endeks olduğunu ve aynı zamanda ölçümünün ucuz ve hızlı olduğunu göstermiştir (Emadi ve Baghernejad 2014; Liu ve ark., 2016; Scudiero ve ark., 2017). Değişebilir sodyum yüzdesi (ESP) toprak sodikliğini değerlendirmek için yaygın olarak kullanılan bir indekstir. Toprağın ESP'sini belirlemek için toprak çözeltisindeki iyonların konsantrasyonlarının $\left(\mathrm{Na}^{+}\right.$, $\left.\mathrm{Ca}^{2+}, \mathrm{Mg}^{2+}\right)$ ve katyon değişim kapasitesinin belirlenmesi gerekmektedir. Sodik toprak, toprak kolloidleri üzerinde fazla miktarda değişebilir $\mathrm{Na}^{+}$içerir ve daha yüksek toprak pH'sına neden olan çözünür karbonatlara sahiptir (Batarseh, 2017). Sodik toprakların temel özelliği çoğu bitkinin büyümesini olumsuz yönde etkileyecek miktarda değişebilir sodyum içermesidir. Aşırı değişebilir sodyum, toprağın verimi ve fiziksel özellikleri üzerinde olumsuz bir etkiye sahiptir ve bunun sonucunda da bitki büyümesinde önemli ölçüde azalma görülür. Sodik topraklarda bulunan aşırı değişebilir sodyum, fiziksel toprak özellikleri üzerinde belirgin bir etkiye sahiptir. Değişebilir sodyum oranı arttıkça, toprak daha fazla dağılma eğilimi gösterir ve bu da toprağın agregatlaşmasına neden olarak toprağın hava ve su geçirgenliğini azaltır. Aşırı değişebilir sodyumun bitki büyümesi üzerindeki bir diğer etkisi ise, toprak $\mathrm{pH}$ 's1 üzerindeki etkisinden kaynaklanmaktadır. Her ne kadar sodik toprakların yüksek pH'sının bitki büyümesi üzerinde doğrudan olumsuz bir etkisi olmasada, bazı temel bitki besin maddelerinin mevcudiyetinin azalması ile sonuçlanmaktadır. Örneğin toprak çözeltisindeki $\mathrm{Ca}^{2+}$ ve $\mathrm{Mg}^{2+}$ elementlerinin konsantrasyonu, çözünebilen sodyum karbonat ile reaksiyona girerek nispeten çözünmeyen kalsiyum ve magnezyum karbonatların oluşumu nedeniyle $\mathrm{pH}$ arttıkça azalır (Abrol ve ark., 1988). Abrol ve ark., (1980) ve Bhargava ve Abrol (1978) çalıştıkları toprakların pH'sı ile değişebilir sodyum yüzdesi arasında bir ilişki olduğunu göstermiş̧ir. Ayrıca çalışmada nispeten kolay bir şekilde belirlenebilen pH'nın değişsebilir sodyum yüzdesinin yaklaşık bir ölçüsü olarak kullanılabileceğini önermişlerdir. Ancak toprağın pH'sı ve ESP'si arasındaki bu ilişkinin sadece belirli tür (saturasyon çamurunda pH'nın 8'in üzerinde olduğu topraklar) topraklar için geçerli olduğunu bildirmişlerdir. Böyle bir ilişsinin tuzlu topraklarda ve pH'nın 8'den daha az olduğu nötr çözünür tuzların hakim olduğu topraklarda mevcut olmadığını ifade etmişlerdir. Gupta ve ark., (1982; 1983) tarafından yapılan çalışmalar pH'nın, değişebilir sodyumun toprak özellikleri üzerindeki etkisinden farklı olarak toprak fiziko-kimyasal davranışını güçlü bir şekilde etkilediğini göstermiştir. $\mathrm{Bu}$ nedenle bu araştırmacılar pH'nın sodik toprak tanımının ayrılmaz bir parçası olması gerektiğini önermişlerdir. Sodik toprakların EC'si düşük, $\mathrm{Na}^{+}$ konsantrasyonu yüksektir (Richards, 1954). Toprak sodikliğindeki değişiminin izlenmesi EC'nin aksine maliyetli ve zaman alıcıdır. Toprak özelliklerinin izlenmesi özellikle geniş alanlarda daima zaman alıcı ve maliyetlidir (Goovaerts, 1998; Allbed ve Kumar, 2013). $\mathrm{Bu}$ nedenle toprak özelliklerinin haritalanması ve enterpolasyonu yeni gereksinimlerdir. Toprak özelliklerinin haritalanması durumunda, sadece alansal ve zamansal değişkenlik belirlenmeyecek, aynı zamanda aşırı toprak örneklemesinin getireceği maliyet ve harcanacak zamanda azalacaktır.

Toprak özelliklerinin kapsamlı bir şekilde değerlendirilmesi ve bunları etkileyen faktörlerinin incelenmesi için toprak özelliklerinin alansal ve zamansal olarak haritalanması önemlidir. Jeoistatistik, 
variogram ve krigleme, toprak özelliklerinin alansal değişkenliğin modellenmesinde ve alansal dağılımın haritalandırılmasında yaygın olarak kullanılmaktadır (Goovaerts, 1998). Klasik istatistik yöntemlerde örneklenmemiş yerlerdeki toprakların yapısal uzaklığa bağlı olan ilişkisi dikkate alınmaz ve her noktadaki örneklerin birbirinden bağımsız olduğu kabul edilir. Bu nedenle uzaysal olarak değişen toprak özelliklerinin analizinde klasik istatistik yöntemlerin yerine jeoistatistik yöntemler son yıllarda yaygın olarak kullanılmaya başlanmıştır. Çok sayıda araştırmacı EC, pH ve ESP'nin alansal dağılımının tahmin edilmesinde jeoistatistiksel yöntemlerin başarı ile kullanılabileceğini bildirmişlerdir (Ardahanlioglu ve ark., 2003, Kılıç ve K1lıç 2007, Emadi ve ark., 2008, Emadi ve Baghernejad 2014). Rodrigues ve ark., (2018) Brezilya'da yarı kurak bir bölgede sulanan bir mango bahçesinde toprak tuzluluğunun alansal dağılımını ve toprak tuzluluğu verilerine dayanarak yönetim sınırlarını belirlemek için çalışma yürütmüşlerdir. Toprakların tekstürü, elektriksel iletkenlik ve değişebilir katyonları belirlenmiştir. Tanımlayıcı istatistik ve jeostatistiksel analiz kullanılarak veriler analiz edilmiştir. Incelenen alanda EC değerlerine göre üç farklı yönetim sınırı belirlenmiştir. Bunlar tüm alanın \% 63 'ünü oluşturan salik toprak, \% 34'ünü oluşturan tuzlu toprak ve \% 3 'ünü oluşturan tuzsuz toprak olarak sinıflandırılmıştır. Rhoades ve Chanduvi, (1999) kil fraksiyonları ile EC arasında pozitif bir korelasyon olduğunu $\left(\mathrm{R}^{2}=0.99\right)$ ve toprakların kil içeriğinin artması ile EC'nin artacağını, azalması durumunda ise azalacağını bildirmişlerdir. Juan ve ark., (2011), arazi yönetimi ve planlama ile ilgili kararlarda özellikle de tuzlulaşmadan dolayı bozulmuş topraklarda jeoistatistiksel analizlerin uygulanabileceğini belirtmişlerdir. Tarımsal uygulamaların ve doğal süreçlerin etkisi nedeniyle toprak tuzluluğu zamansal ve alansal olarak ciddi şekilde değişmekle birlikte iklim, arazi kullanımı, topoğrafya ve bitki örtüsü gibi faktörlere bağlıdır (Shahabi ve ark., 2017). Cemek ve ark., (2007), toprak tuzluluğu ve alkalinitesi ile ilgili olarak bazı toprak özelliklerinde uzaysal değişkenliğin değerlendirilmesinde, toprak özelliklerindeki güçlü mekansal bağımlılığının, yeraltı suyu seviyesi, drenaj, sulama sistemleri ve mikrotopografya gibi dış etkenlerden kaynaklandığını doğrulamışlardır. ZareMehrjardi ve ark., (2010), ordinary kriging (OK) ve Cokriging yöntemlerinin toprak özelliklerinin alansal dağılımını tahmin etmek için ters mesafe ağırlıklı enterpolasyon (IDW) yönteminden daha iyi olduğunu bildirmişlerdir. Poshtmasari ve ark., (2012) Kuzey İran'ın Golestan eyaletindeki tarım alanlarında $\mathrm{pH}$ ve EC'yi tahmin için en iyi yöntemin küresel ve üssel modeller ile kriging yöntemi olduğunu bildirmişlerdir. Bilgili (2013), Türkiye'nin Güneydoğusunda bulunan yarı kurak bir bölgede toprak tuzluluğunu incelemek için birçok kriging tekniği kullanmıştır. Çalışmada toprak tuzluluğunun alansal bağımlılık gösterdiğini ve toprak tuzluluk haritalarının enterpolasyonu için kriging tekniklerinin verimli şekilde kullanılabileceğini doğrulamıştır. Akramkhanov ve ark., (2014) Özbekistan'da kurak bir bölgede düze yakın sulanmış arazilerde toprak tuzluluğunun alansal dağılımını incelemiş ve toprak tuzluluğunun kısa mesafelerde bile (40 m) çok değişkenlik gösterdiğini bildirmişlerdir.

Bu çalışma 2010 ve 2016 yıllarında Bafra ovası sağ sahil sulama alanındaki toprakların tuzluluk ve sodikliğinde meydana gelen alansal ve zamansal değişimleri belirlemek ve sulamanın toprak tuzluluğu ve sodikliği üzerine etkisinin değerlendirilmesi amacıyla yapılmıştır. Çalışmada elde edilen sonuçların toprakların sürdürülebilir kullanımları ile ilgili bilgi vermesi ve gelecekteki kullanışlı yönetim statejilerinin geliştirilmesinde yararlı olması beklenmektedir.

\section{Materyal ve Yöntem}

\section{1. Çalışma Alanı}

Çalışma alanı Samsun ili Bafra ilçesi ile Karadeniz kıyı bölgesi $\left(41^{\circ} 10^{\prime}-41^{\circ} 45^{\prime}\right.$ kuzey elemleri ve $35^{\circ} 30^{\prime}$ - $36^{\circ} 15^{\prime}$ doğu boylamları) arasında kalmaktadır. Çalışma alanının büyüklüğü yaklaşık 10000 ha'dır. Çalışma alanı Kızılırmak nehrinin farklı zamanlarda getirdiği alüvyal depozitlerden oluşmaktadır. Bafra ovasının başlıca su kaynağı Kızılırmak nehridir. Çalışma alanında iklim özellikleri olarak tipik ılıman Karadeniz bölgesi iklimi görülmektedir. Bölgenin uzun yıllar ortalama en düşük sıcaklık değeri $5.7^{\circ} \mathrm{C}$ ile Şubat, ortalama en yüksek sıcaklık değeri $23.0{ }^{\circ} \mathrm{C}$ ile Ağustos aylarında görülmektedir. Yıllık toplam yağış değerleri uzun yıllar göz önüne alındığında $794.2 \mathrm{~mm}$ olarak gerçekleşmektedir (Taşan, 2018). Çalışma alanının konumu ve örnekleme noktaları Şekil 1'de gösterilmiştir.

\subsection{Toprak örneklemesi ve laboratuvar analizleri}

Çalışma alanı topraklarının tuzluluk ve sodiklik durumlarını belirlemek amaciyla 2010 ve 2016 yıllarında sulama öncesi ve sulama sonrasında olacak şekilde üç farklı dönemde (Nisan 2010 ve Nisan-Eylül 2016) $0-30,30-60,60-90$ ve $90-120 \mathrm{~cm}$ derinliklerden toprak örnekleri alınmıştır. 2010 yılında 100 noktadan ve 2016 yilında 112 noktadan bozulmuş toprak örnekleri alınmıştır. Örnek alınan noktaların koordinatları GPS ile kaydedilmiştir. Toprak örnekleri kurutulup $2 \mathrm{~mm}$ 'lik elekten geçirilerek analize hazır hale getirilmiştir. Toprak tekstürünün belirlenmesinde Bouyoucos hidrometre yöntemi (Bouyoucos, 1951) kullanılmıştır. Toprakların elektriksel iletkenlik değerleri, 1:2.5 oranında hazırlanan toprak-su karışımında elektriksel kondaktivite aleti ile belirlenmiştir (Richards, 1954). Toprakların pH değerleri 1:2.5 toprak-su karışımında cam elektrotlu pHmetre ile ölçülmüştür (Gee ve Bauder, 1986). Toprakların $\mathrm{CaCO} 3$ içeriği ise Scheibler kalsimetresiyle \% olarak belirlenmiştir (Kacar, 1994). Değişebilir Na, 
$\mathrm{K}$, Ca ve Mg miktarları Richards (1954) tarafindan bildirildiği şekilde toprak örnekleri $1.0 \mathrm{~N}$ Amonyum Asetat $(\mathrm{pH}=7)$ ile ekstrakte edilmiştir. Ekstrakta $\mathrm{Na}$ ve

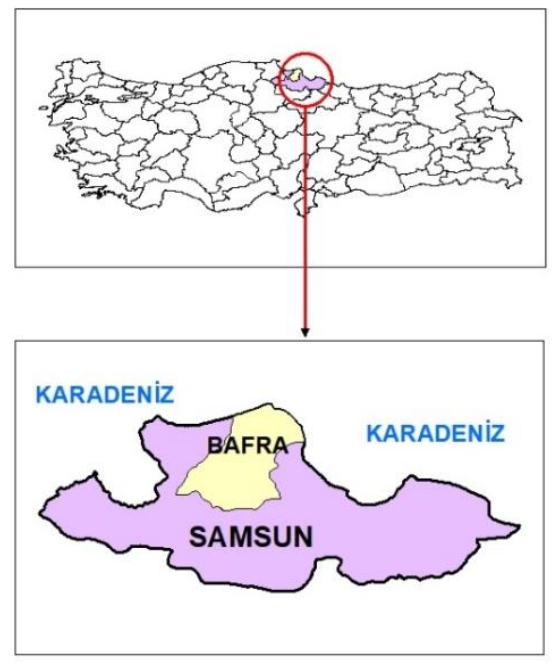

$\mathrm{K}$, fleymfotometrik yöntemle, $\mathrm{Ca}$ ve $\mathrm{Mg}$ ise EDTA ile titrimetrik olarak belirlenmiştir.

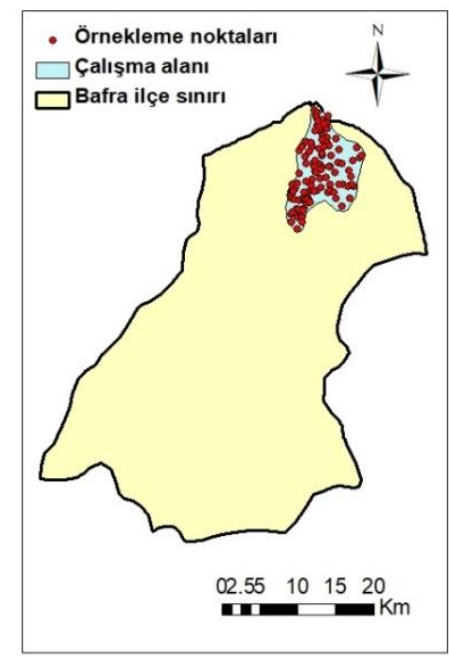

Şekil 1. Çalışma alanı konumu ve örnekleme noktaları

Değişebilir sodyum yüzdesi (ESP) değerleri (Richards, 1954)'de verilen eşitlik 1 yardımıyla hesaplanmıştır.

$E S P=\frac{\text { Değişebilir } N a\left(m e q 100 g^{-1}\right)}{K D K\left(\text { meq } 100 g^{-1}\right)} x 100$

\subsection{Jeoistatistiksel analizler}

Çalışma alanı toprak özelliklerinin haritalanmasında jeoistatistiksel yöntemler kullanılmıştır. Haritalanan özelliklere ait semivariogramlar ArcGIS 10.0 ve GS+ 10.0 paket programları kullanılarak modellenmiştir. Modeller kullanılarak en uygun enterpolasyon yöntemi seçilmiş ve çalışma alanı topraklarının tuzluluk ve sodiklik özellikleri haritalanmıştır. Variogramlara ait range, sill ve nugget değerleri tespit edilerek, her bir özelliğin mesafeye bağımlılığı belirlenmiştir. Toplam değişkenliğin yüzdesi olarak ifade edilen Nugget etki varyansı (Nugget/Sill), toprak değişkenlerinin uzaysal bağımlılığını sınıflandırmak için kullanılmıştır. Bu oran $\% 25$ 'e eşit veya daha düşük ise kuvvetli uzaysal bağımlı, \% 25-\% 75 arasında ise orta derecede bağımlı ve $\% 75$ 'den büyük ise zayıf uzaysal bağımlı olarak siniflandırılmaktadır (Cambardella ve ark., 1994). Semivariogram'ın eğimi sıfira yaklaştı̆̆ında değişkenliğin rastgele olduğu (uzaysal bağımlılık yok) kabul edilir. Eşitlik 2 kullanılarak semivariogramlar hesaplanmıştır.

$$
\gamma(h)=\frac{1}{2 N(h)} \sum_{i=1}^{N(h)}\left(Z\left(x_{i}\right)-Z\left(x_{i}+h\right)\right)^{2}
$$

Burada; N(h), $h$ mesafesi ile birbirinden ayrılan deneysel veri çiftlerinin sayısını, $Z\left(x_{i}\right)$ ve $Z\left(x_{i}+h\right)$ ise $x_{i}$ ve $\left(\mathrm{x}_{\mathrm{i}}+\mathrm{h}\right)$ noktalarındaki ölçüm değerlerini ifade etmektedir. Semivariogramlar her bir $\mathrm{h}$ değeri ile birbirinden ayrılan örnek çiftlerinin varyansı ile mesafe arasındaki ilişkiyi grafiksel olarak ifade etmekte ve uzaysal bağımlılı̆̆ tanımlamaktadır (Journel ve Huijbregts, 1978; Başbozkurt ve ark., 2013).

Modeller içerisinden en yüksek $r^{2}$ ve en düşük hata kareler toplamını (RSS) veren model en uygun model olarak seçilmiştir. Jeoistatistiksel değerlendirme sonucu elde edilen parametreler kullanılarak ArcGIS 10.0 paket programı ile krigleme haritaları oluşturulmuştur. Krigleme, ordinary kriging yöntemi ile yapılmış ve ilgili değişkenlerin farklı katmanlardaki alansal ve zamansal değişim haritaları hazırlanmıştır.

\section{Bulgular ve Tartışma}

\subsection{Tanımlayıcı istatistikler}

Jeoistatistik analiz için uygun yöntemin seçilmesinin en önemli ön şartı verilerin değerlendirilmesidir. Çalı̧̧ma alanından 2010 yılında sulama öncesi dönemde ve 2016 yılında sulama öncesi ve sonrası dönemde alınan toprakların $\mathrm{EC}, \mathrm{pH}$, ESP ve $\mathrm{CaCO}_{3}$ değerlerine ait en küçük, en büyük, ortalama, standart sapma, çarpıklık ve basıklık değerleri Çizelge 1'de, tekstür özelliklerinin tanımlayıcı istatistik parametreleri ise Çizelge 2'de verilmiştir. Çalışma alanı topraklarının EC değerlerinin ortalamas1 2010 yılı sulama öncesi dönemde 0.55 ile $0.79 \mathrm{dS} \mathrm{m}^{-1}$ arasinda, 2016 yılı sulama öncesi dönemde 0.61 ile $0.67 \mathrm{dS} \mathrm{m}^{-1}$ arasında değişim gösterirken, 2016 sulama sonrası dönemde ise 0.66 ile $0.78 \mathrm{dS} \mathrm{m}^{-1}$ arasında değişmiştir (Çizelge 1). Her üç dönemde de genel olarak en yüksek elektriksel iletkenlik değeri yüzey toprağında bulunmuş, derinlik arttıkça EC değerleri azalmıştır. 
Çizelge 1. Çalışma alanı topraklarının bazı kimyasal özelliklerine ait tanımlayıcı istatistikler

\begin{tabular}{|c|c|c|c|c|c|c|c|c|c|c|}
\hline Dönem & Toprak özelliği & Derinlik $(\mathrm{cm})$ & Min & $\operatorname{Max}$ & $\overline{\mathrm{AO}}$ & SS & VK & Basıklık & Çarpıklık & Dağılım \\
\hline \multirow{16}{*}{$\begin{array}{l}2010 \text { Sulama } \\
\text { Öncesi }\end{array}$} & \multirow{4}{*}{ EC } & $0-30$ & 0.31 & 4.30 & 0.79 & 0.61 & 77.81 & 15.30 & 3.54 & $\log$ \\
\hline & & $30-60$ & 0.25 & 2.28 & 0.65 & 0.37 & 57.30 & 8.51 & 2.70 & $\log$ \\
\hline & & $60-90$ & 0.18 & 3.25 & 0.64 & 0.47 & 73.53 & 14.71 & 3.42 & $\log$ \\
\hline & & $90-120$ & 0.16 & 1.44 & 0.55 & 0.28 & 50.24 & 2.06 & 1.53 & $\log$ \\
\hline & \multirow{4}{*}{$\mathrm{pH}$} & $0-30$ & 6.15 & 9.34 & 7.35 & 0.45 & 6.08 & 5.50 & 1.40 & $\log$ \\
\hline & & $30-60$ & 6.49 & 9.11 & 7.59 & 0.42 & 5.51 & 1.84 & 0.73 & Karekök \\
\hline & & $60-90$ & 6.81 & 9.07 & 7.93 & 0.44 & 5.58 & 0.49 & 0.12 & Normal \\
\hline & & $90-120$ & 6.94 & 9.23 & 8.03 & 0.42 & 5.28 & 1.27 & 0.40 & Normal \\
\hline & \multirow{4}{*}{ ESP } & $0-30$ & 2.07 & 49.16 & 9.19 & 8.20 & 89.24 & 11.91 & 3.31 & $\log$ \\
\hline & & $30-60$ & 3.07 & 58.07 & 10.38 & 9.29 & 89.58 & 10.17 & 3.01 & $\log$ \\
\hline & & $60-90$ & 3.09 & 36.92 & 9.90 & 7.71 & 77.83 & 4.92 & 2.35 & $\log$ \\
\hline & & $90-120$ & 2.66 & 47.72 & 9.29 & 9.64 & 103.78 & 8.40 & 3.01 & $\log$ \\
\hline & \multirow{4}{*}{$\mathrm{CaCO}_{3}$} & $0-30$ & 0.24 & 18.24 & 5.97 & 4.58 & 76.81 & -0.72 & 0.50 & Normal \\
\hline & & $30-60$ & 0.33 & 24.72 & 7.18 & 5.52 & 76.76 & 0.00 & 0.60 & Karekök \\
\hline & & $60-90$ & 0.40 & 27.39 & 11.62 & 6.37 & 54.78 & -0.39 & -0.06 & Normal \\
\hline & & $90-120$ & 0.40 & 31.20 & 12.32 & 6.19 & 50.24 & 0.51 & 0.02 & Normal \\
\hline \multirow{16}{*}{$\begin{array}{l}2016 \text { Sulama } \\
\text { Öncesi }\end{array}$} & \multirow{4}{*}{ EC } & $0-30$ & 0.21 & 6.31 & 0.67 & 0.60 & 88.90 & 73.66 & 7.82 & $\log$ \\
\hline & & $30-60$ & 0.20 & 4.33 & 0.65 & 0.47 & 72.57 & 33.24 & 4.79 & $\log$ \\
\hline & & $60-90$ & 0.20 & 1.97 & 0.61 & 0.36 & 58.93 & 3.31 & 1.79 & $\log$ \\
\hline & & $90-120$ & 0.16 & 2.45 & 0.61 & 0.41 & 68.49 & 5.35 & 2.19 & $\log$ \\
\hline & \multirow{4}{*}{$\mathrm{pH}$} & $0-30$ & 6.73 & 8.65 & 7.48 & 0.33 & 4.36 & 1.11 & 0.26 & Normal \\
\hline & & $30-60$ & 6.66 & 8.82 & 7.65 & 0.33 & 4.32 & 2.33 & 0.41 & Normal \\
\hline & & $60-90$ & 6.91 & 9.23 & 7.90 & 0.41 & 5.23 & 1.68 & 0.57 & Karekök \\
\hline & & $90-120$ & 6.68 & 9.28 & 8.04 & 0.40 & 4.96 & 2.58 & 0.24 & Normal \\
\hline & \multirow{4}{*}{ ESP } & $0-30$ & 1.06 & 72.76 & 6.07 & 7.15 & 117.82 & 70.31 & 7.76 & $\log$ \\
\hline & & $30-60$ & 1.16 & 55.18 & 7.50 & 7.77 & 103.52 & 21.06 & 4.30 & $\log$ \\
\hline & & $60-90$ & 1.75 & 49.40 & 8.68 & 8.63 & 99.34 & 10.78 & 3.25 & $\log$ \\
\hline & & $90-120$ & 2.94 & 65.65 & 9.63 & 10.14 & 105.34 & 11.84 & 3.30 & $\log$ \\
\hline & \multirow{4}{*}{$\mathrm{CaCO}_{3}$} & $0-30$ & 1.21 & 16.30 & 7.15 & 4.16 & 58.15 & -1.04 & 0.44 & Normal \\
\hline & & $30-60$ & 1.21 & 18.64 & 7.74 & 4.48 & 57.81 & -1.16 & 0.36 & Normal \\
\hline & & $60-90$ & 1.45 & 33.90 & 12.05 & 6.69 & 55.55 & -0.02 & 0.43 & Normal \\
\hline & & $90-120$ & 1.45 & 32.29 & 14.69 & 6.55 & 44.60 & 0.01 & 0.01 & Normal \\
\hline \multirow{16}{*}{$\begin{array}{l}2016 \text { Sulama } \\
\text { Sonras1 }\end{array}$} & \multirow{4}{*}{$\mathrm{EC}$} & $0-30$ & 0.27 & 5.34 & 0.77 & 0.53 & 68.44 & 50.74 & 6.07 & $\log$ \\
\hline & & $30-60$ & 0.27 & 5.54 & 0.78 & 0.57 & 73.26 & 44.52 & 5.74 & $\log$ \\
\hline & & $60-90$ & 0.26 & 5.77 & 0.73 & 0.60 & 81.69 & 45.72 & 5.90 & $\log$ \\
\hline & & $90-120$ & 0.21 & 5.07 & 0.66 & 0.52 & 78.69 & 45.36 & 5.72 & $\log$ \\
\hline & \multirow{4}{*}{$\mathrm{pH}$} & $0-30$ & 6.97 & 9.23 & 7.81 & 0.41 & 5.21 & 1.34 & 0.44 & Normal \\
\hline & & $30-60$ & 7.06 & 9.83 & 7.94 & 0.36 & 4.56 & 5.85 & 1.18 & $\log$ \\
\hline & & $60-90$ & 7.25 & 9.93 & 8.19 & 0.43 & 5.25 & 3.14 & 0.78 & Karekök \\
\hline & & $90-120$ & 7.07 & 9.86 & 8.39 & 0.45 & 5.39 & 1.93 & 0.56 & Karekök \\
\hline & \multirow{4}{*}{ ESP } & $0-30$ & 1.18 & 44.46 & 6.64 & 5.92 & 89.19 & 27.67 & 4.73 & $\log$ \\
\hline & & $30-60$ & 1.68 & 51.82 & 7.41 & 7.22 & 97.41 & 19.65 & 4.08 & $\log$ \\
\hline & & $60-90$ & 1.56 & 50.27 & 8.35 & 8.21 & 98.27 & 13.25 & 3.48 & $\log$ \\
\hline & & $90-120$ & 2.27 & 47.42 & 8.64 & 8.34 & 96.43 & 10.16 & 2.99 & $\log$ \\
\hline & \multirow{4}{*}{$\mathrm{CaCO}_{3}$} & $0-30$ & 1.30 & 16.88 & 7.21 & 4.12 & 57.09 & -1.10 & 0.43 & Normal \\
\hline & & $30-60$ & 1.62 & 20.45 & 7.42 & 4.32 & 58.24 & -0.68 & 0.56 & Karekök \\
\hline & & $60-90$ & 1.30 & 24.42 & 10.25 & 5.49 & 53.51 & -0.64 & 0.21 & Karekök \\
\hline & & $90-120$ & 1.62 & 28.96 & 13.63 & 6.36 & 46.71 & -0.48 & 0.01 & Normal \\
\hline
\end{tabular}

Min: Minimum değer, Max: Maksimum değer, AO: Aritmetik ortalama, SS: Standart sapma, VK: Varyasyon katsayısı (\%), EC: Elektriksel iletkenlik (dS m$\left.{ }^{-1}\right)$, ESP: Değişebilir sodyum yüzdesi 
Ortalama elektriksel iletkenlik değerleri incelendiğinde ova topraklarında tuzluluk problemi olmadığı söylenebilir. Ancak en yüksek EC değerleri arasında 2010 yılında $4.30 \mathrm{dS} \mathrm{m}^{-1}, 2016$ y1lı sulama öncesinde $6.31 \mathrm{dS} \mathrm{m}^{-1}$ ve 2016 y1l sulama sonrasinda $5.77 \mathrm{dS} \mathrm{m}^{-1}$ bulunması ovada yer yer tuzluluk probleminin olduğuna işaret etmektedir. Ayrıca sulama öncesi ve sonrası dönemler karşılaştırıldığında tuz içeren gübrelerin kullanımına ve uygulanan sulama suyunun miktar ve kalitesine bağlı olarak tuzluluk değeri artış göstermiştir. Ortalama toprak pH değeri 2010 y1lında 7.35 ile 8.03 arasında, 2016 yılı sulama öncesinde 7.48 ile 8.04 arasında ve 2016 yılı sulama sonrasında ise 7.81 ile 8.39 arasında değişmiştir. Toprakların pH'sı EC değerinin aksine derinlikle birlikte artış göstermiştir. Bafra ovasında yapılan bir çalışmada toprakların ortalama $\mathrm{pH}$ değerlerinin 0-30, 30-60, 60-90 ve 90-120 cm toprak katmanları için sirasıyla $8.0,8.2,8.3$ ve 8.4 olduğu belirlenmiştir (Cemek ve ark., 2007). Toprakların ESP içerikleri 2010 y1lı sulama öncesi dönemde 2.07 ile 58.07 arasında değişim gösterirken, 2016 yllı sulama öncesi dönemde 1.06 ile 72.76 arasında değişmiştir. 2016 yılı sulama sonrası dönemde ise 1.18 ile 51.82 arasında değişim göstermiştir. Her üç dönemde de bütün katmanlar birlikte değerlendirildiğinde en düşük ESP yüzey katmanında bulunmuş, derinlik arttıkça ESP içeriği genel olarak artmıştır. Çalışma alanı topraklarının ortalama $\mathrm{CaCO}_{3}$ içerikleri 2010 yılı sulama öncesinde 5.97 ile 12.32 arasında, 2016 yılı sulama öncesinde 7.15 ile 14.69 arasında ve 2016 yılı sulama sonrasında ise 7.21 ile 13.63 değerleri arasında değişmiş̧ir (Çizelge 1). Taşova ve Akın (2013) toprakların $\mathrm{CaCO}_{3}$ içeriğini 1'den küçük ise çok az kireçli, 1-5 arasında ise az kireçli, 5-15 arasında ise orta kireçli, 15-25 arasında ise çok kireçli ve 25 'den büyük olması durumunda ise çok fazla kireçli olarak sınıflandırmışlardır. Bu sınıflandırmaya göre çalışma alanı topraklarının orta kireçli sınıfta olduğu belirlenmiştir. Derinlik arttıkça toprakların kireç içeriğinin artması ana materyale yaklaşmasına bağlanabilir (Büyükgüner, 2007). Toprakların kil içeriği ortalama \% 36.94 ile \% 42.46 arasında, kum içeriği ortalama \% 21.27 ile \% 22.48 arasında ve silt içeriği ortalama \% 35.88 ile \% 37.37 arasında değişmiştir (Çizelge 2). Çalışma alanı topraklarının kum içeriği genel olarak derinlikle birlikte artış gösterirken, kil içeriği derinlikle birlikte azalmıştır.

Çizelge 2. Çalışma alanı topraklarının bazı fiziksel özelliklerine ait tanımlayıcı istatistikler

\begin{tabular}{clcccccccl}
\hline Özellik & Derinlik $(\mathrm{cm})$ & Min. & Max. & AO & S.S & VK & Basıklık & Çarpıklık & Dağılım \\
\hline \multirow{5}{*}{ Kum (\%) } & $0-30$ & 8.39 & 48.05 & 22.48 & 7.66 & 34.05 & 0.38 & 0.64 & Karekök \\
& $30-60$ & 0.62 & 49.22 & 21.27 & 8.49 & 39.92 & 0.69 & 0.61 & Karekök \\
& $60-90$ & 5.61 & 84.54 & 22.12 & 14.40 & 65.10 & 7.10 & 2.32 & Log \\
& $90-120$ & 4.00 & 86.54 & 24.69 & 17.11 & 69.30 & 2.21 & 1.53 & Log \\
\hline \multirow{5}{*}{ Kil (\%) } & $0-30$ & 5.81 & 69.74 & 41.64 & 11.98 & 28.78 & 0.09 & -0.25 & Normal \\
& $30-60$ & 5.88 & 69.56 & 42.46 & 13.22 & 31.14 & -0.40 & -0.31 & Normal \\
& $60-90$ & 5.67 & 67.62 & 40.79 & 15.50 & 37.99 & -0.75 & -0.32 & Normal \\
& $90-120$ & 6.04 & 81.78 & 36.94 & 17.42 & 47.14 & -0.80 & 0.09 & Normal \\
\hline \multirow{5}{*}{ Silt (\%) } & $0-30$ & 20.78 & 63.71 & 35.88 & 8.15 & 22.72 & 1.06 & 0.81 & Karekök \\
& $30-60$ & 19.37 & 68.51 & 36.26 & 8.84 & 24.37 & 1.28 & 0.97 & Karekök \\
& $60-90$ & 7.45 & 78.13 & 37.09 & 11.27 & 30.38 & 1.54 & 0.57 & Karekök \\
& $90-120$ & 7.43 & 71.40 & 38.37 & 11.39 & 29.68 & 0.35 & 0.10 & Normal \\
\hline
\end{tabular}

Min: Minimum değer, Max: Maksimum değer, AO: Aritmetik ortalama, SS: Standart sapma, VK: Varyasyon katsayısı (\%)

Toprak özelliklerine ait veri setlerinin normal dağglım göstermesi uygulanacak istatistiksel yöntemler açısından önemlidir. Veri setlerinin normal dağılıma uygunluğunun göstergelerinden olan çarpıklık ve basıklık katsayıları Çizelge 1'de verilmiştir. Webster (2001) toprak verilerinde normal dağılımla ilgili en ciddi ayrılma göstergesinin çarpıklık değeri olduğu ifade etmiştir. Eğer çarpıklık değeri 0.5 'den küçük ise veri normal dağılım göstermiş ve herhangi bir dönüşüm yapılmamıştır. Çarpıklık değeri $>0.5$ ve $\leq 1.0$ ise bu durumda karekök alınarak veriler normal dağılıma dönüştürülmüş ve eğer çarpıklık değeri $>1.0$ ise bu durumda da log-normal dönüşüm uygulanmıştır. Buna göre her üç dönemde de EC ve ESP içerikleri tüm katmanlarda log-normal dağılım göstermiştir.

Varyasyon katsayısı (VK), toprak özelliklerinin değişkenliğini tanımlamak için diğer parametrelere göre en ayırt edici faktördür (Zhang ve ark., 2007). Wilding (1985) toprak özelliklerinin değişkenlik derecesini belirlemek için bir sınıflandırma yapmıştır. Buna göre, varyasyon katsayısı $15^{\prime}$ den küçük olanlar az değişken, 16-35 arası olanlar orta derecede değişken ve 36'dan büyük olanlar yüksek derecede değişken olarak sınıflandırılmıştır. Bu sınıflandırmaya göre her üç dönem ve dört derinlikte de toprakların EC, ESP ve $\mathrm{CaCO}_{3}$ özellikleri yüksek derecede değişkenlik gösterirken, $\mathrm{pH}$ az değişkenlik göstermiştir. Moasheri 
ve Foroughifar (2013), pH için düşük değiş̧kenlik katsayısının topraktaki ana madde bileşiminden, yüksek değişkenlik katsayısının ise gübreleme ve arazi kullanım tipi gibi arazi yönetim faktörlerinden kaynaklanabileceğini bildirmişlerdir.

Varyasyon katsayılarına göre yüksek değişkenlik gösteren verilerde uzaysal bağımlılığın düşük, düşük değişkenlik gösteren verilerde ise uzaysal bağımlılığın yüksek olması beklenmektedir (Akbaş, 2011; Tekin ve ark., 2011). Emadi ve Baghernejad (2014) çalışmalarında ölçülen tüm toprakların EC değerlerinin genellikle heterojen olduğunu ve yüksek değişkenliğe sahip olduğunu (VK \% 36'dan büyük) doğrulamıştır. Fiziksel özellikler incelendiğinde $0-30 \mathrm{~cm}$ derinlikteki kum içeriği orta derecede, diğer katmanlardaki kum içerikleri ise yüksek derecede değişkenlik göstermişlerdir. $0-30 \mathrm{~cm}$ ve $30-60 \mathrm{~cm}$ derinliklerindeki kil içeriği orta derecede değișkenlik gösterirken, 60-90 $\mathrm{cm}$ ve 90-120 cm derinliklerindeki kil içerikleri yüksek derecede değişkenlik göstermişlerdir (Çizelge 2). Çalışma alanı topraklarının silt içeriği ise tüm derinliklerde orta derecede değişkenlik göstermiştir. Kum ve kil içeriğinin yüksek derecede değişkenlik göstermesi alüvyal ana materyalin çalışma alanında farklılık göstermesi ve çalışma alanının geniş olmasına bağlanabilir.

\subsection{Jeoistatistiksel analiz}

Çalışma alanı topraklarının EC ve ESP içeriklerinin uzaysal yapılarının belirlenmesi amacıyla her bir özellik için deneysel semivariogramlar oluşturulmuştur (Çizelge 3). Semivariogramların oluşturulmasında yönlere göre olası bağımlılığı (anizotropi) test etmek amaciyla, farklı dört yönde $(0,45,90$ ve 1350) hesaplamalar yapılmıştır. İncelenen özellikler izotropik bir yapı göstermiştir. Bu durum çalışma alanının düz ve düze yakın (\% 0-2) topoğrafik özelliğine ve benzer ana materyal üzerinde oluşum göstermesine bağlanmıştır. Jeoistatistiksel analiz, her dört toprak katmanında toprakların EC ve ESP'si için farklı uzaysal dağılım modelleri ve uzaysal bağımlılık seviyelerini ortaya çıkarmışırı (Çizelge 3; Şekil 2; Şekil 3). Toprakların tuzluluk ve sodikliğinin modellenmesinde küresel, üssel ve gausiyan modeller kullanılmıştır. Modellerin belirlenmesinde $r^{2}$ ve RSS değerleri dikkate alınmış ve en yüksek $r^{2}$ değeri ile en düşük RSS değerlerini veren model tercih edilmiştir. 2010 yilı sulama öncesi dönemde EC içerikleri $90-120 \mathrm{~cm}$ haricinde tüm katmanlarda gausiyan model ile modellenmiştir (Şekil 2). Değişebilir sodyum yüzdesi ise tüm derinliklerde gausiyan model ile modellenmiştir (Şekil 3). 2016 yılı sulama öncesi dönemde EC, $0-30$ ve $60-90 \mathrm{~cm}$ derinliklerde gausiyan model, $30-60$ ve $90-120 \mathrm{~cm}$ derinliklerde ise küresel model ile tanımlanmıştır.

Çizelge 3. Toprakların EC ve ESP'leri için en iyi uygulanan semivariogram modelleri ve parametreleri

\begin{tabular}{|c|c|c|c|c|c|c|c|c|c|}
\hline Dönem & Özellik & Derinlik & Model & $\begin{array}{c}\text { Co } \\
\text { (Nugget) }\end{array}$ & $\begin{array}{c}\mathrm{Co}+\mathrm{C} \\
\text { (Sill) }\end{array}$ & $\begin{array}{l}\text { Ao (m) } \\
\text { (Range) }\end{array}$ & $\begin{array}{c}\text { Uzaysal Bağ } \\
(\%)\end{array}$ & $r^{2}$ & RSS \\
\hline \multirow{8}{*}{2010 Sulama Öncesi } & \multirow{4}{*}{ EC } & $0-30$ & Gausiyan & 0.10 & 0.19 & 4830 & Orta & 0.82 & 0.002 \\
\hline & & $30-60$ & Gausiyan & 0.12 & 0.23 & 5370 & Orta & 0.94 & 0.001 \\
\hline & & $60-90$ & Gausiyan & 0.15 & 0.31 & 9630 & Orta & 0.66 & 0.007 \\
\hline & & $90-120$ & Küresel & 0.11 & 0.26 & 10700 & Orta & 0.73 & 0.008 \\
\hline & \multirow{4}{*}{ ESP } & $0-30$ & Gausiyan & 0.13 & 0.37 & 5390 & Orta & 0.86 & 0.012 \\
\hline & & $30-60$ & Gausiyan & 0.20 & 0.41 & 5390 & Orta & 0.78 & 0.010 \\
\hline & & $60-90$ & Gausiyan & 0.17 & 0.38 & 5910 & Orta & 0.91 & 0.005 \\
\hline & & $90-120$ & Gausiyan & 0.15 & 0.35 & 5340 & Orta & 0.90 & 0.005 \\
\hline \multirow{8}{*}{2016 Sulama Öncesi } & \multirow{4}{*}{$\mathrm{EC}$} & $0-30$ & Gausiyan & 0.11 & 0.22 & 5280 & Orta & 0.92 & 0.001 \\
\hline & & $30-60$ & Küresel & 0.09 & 0.25 & 8800 & Orta & 0.79 & 0.006 \\
\hline & & $60-90$ & Gausiyan & 0.16 & 0.34 & 6870 & Orta & 0.96 & 0.002 \\
\hline & & $90-120$ & Küresel & 0.14 & 0.39 & 16060 & Orta & 0.96 & 0.002 \\
\hline & \multirow{4}{*}{ ESP } & $0-30$ & Gausiyan & 0.19 & 0.38 & 4550 & Orta & 0.91 & 0.004 \\
\hline & & $30-60$ & Gausiyan & 0.16 & 0.34 & 4460 & Orta & 0.84 & 0.007 \\
\hline & & $60-90$ & Küresel & 0.14 & 0.41 & 10350 & Orta & 0.92 & 0.006 \\
\hline & & $90-120$ & Üssel & 0.13 & 0.56 & 7960 & Güçlü & 0.89 & 0.012 \\
\hline \multirow{8}{*}{2016 Sulama Sonras1 } & \multirow{4}{*}{$\mathrm{EC}$} & $0-30$ & Üssel & 0.09 & 0.22 & 3450 & Orta & 0.81 & 0.002 \\
\hline & & $30-60$ & Gausiyan & 0.10 & 0.21 & 4170 & Orta & 0.84 & 0.002 \\
\hline & & $60-90$ & Gausiyan & 0.12 & 0.27 & 5630 & Orta & 0.93 & 0.002 \\
\hline & & $90-120$ & Gausiyan & 0.15 & 0.37 & 7380 & Orta & 0.87 & 0.008 \\
\hline & \multirow{4}{*}{ ESP } & $0-30$ & Üssel & 0.13 & 0.25 & 3100 & Orta & 0.84 & 0.001 \\
\hline & & $30-60$ & Gausiyan & 0.18 & 0.35 & 4910 & Orta & 0.93 & 0.003 \\
\hline & & $60-90$ & Gausiyan & 0.22 & 0.47 & 10590 & Orta & 0.80 & 0.009 \\
\hline & & $90-120$ & Üssel & 0.18 & 0.48 & 3860 & Orta & 0.72 & 0.021 \\
\hline
\end{tabular}


ESP ise $0-30$ ve $30-60 \mathrm{~cm}$ derinliklerde gausiyan, $60-90 \mathrm{~cm}$ derinlikte küresel ve $90-120 \mathrm{~cm}$ derinlikte üssel model ile modellenmiştir. 2016 yılı sulama sonrası dönemde ise EC, 0-30 cm haricinde gausiyan model ve ESP, $0-30 \mathrm{~cm}$ ve $90-120 \mathrm{~cm}$ derinliklerde üssel model ile modellenmiştir.

Toprak özelliklerin uzaysal değişkenliklerinin ifade edilmesinde nugget semivaryansin toplam semivaryansa oranının yüzde olarak ifadesi yaygın olarak kullanılmaktadır. Cambardella ve ark., (1994)'de verilen esaslara göre çalışma alanı topraklarının uzaysal bağımlılıkları değerlendirildiğinde 2016 yılı sulama öncesi dönemde 90-120 cm derinlikteki ESP haricinde her üç dönem ve dört derinlik için EC ve ESP özelliklerinin orta derecede uzaysal bağımlılık gösterdiği belirlenmiştir (Çizelge 3). Örnekler arasındaki uzaysal bağımlılığın güçlü olması, kısa mesafelerde örnekler arası benzerliğin ortadan kalkmadığını göstermektedir. Jeoistatistiksel analizde nugget değeri, genellikle örnekleme aralığında tespit edilemeyen ölçümlerin yanlışlı̆̆ından kaynaklanan rastgele varyasyonu temsil etmektedir (Trangmar ve ark., 1986). Sill değeri, semivariogram modelinin üst sinırıdır (Webster ve Oliver, 2001). Örneklerin uzaysal olarak birbirleriyle bağımlı oldukları maksimum mesafeyi gösteren range değerleri 2010 y1lı sulama öncesi dönemde EC özelliği için 4830 ile $10700 \mathrm{~m}$ arasında iken, ESP özelliği için 5340 ile $5910 \mathrm{~m}$ arasında değişmiştir. 2016 yılı sulama öncesi dönemde range değerleri EC için 5280 ile $16060 \mathrm{~m}$ arasında ve ESP için 4460 ile $10350 \mathrm{~m}$ arasında değişmiştir. Son olarak 2016 yılı sulama sonrası dönemde örneklerin uzaysal olarak bağımlı oldukları maksimum mesafe EC için $7380 \mathrm{~m}$ ve ESP için $10590 \mathrm{~m}$ olarak belirlenmiştir (Çizelge 3). Çalışma alanı topraklarının EC ve ESP özelliklerinin yapısal uzaklıkları farklı dönemlerde geniş bir aralıkta değişmiştir. Çalışma alanındaki yeraltı suyu seviyesi, drenaj ve sulama sistemleri gibi dışsal faktörlerin incelenen toprak özelliklerinin uzaysal bağımlılı̆̆ını etkileyen önemli faktörler olabileceğini göstermektedir. a)
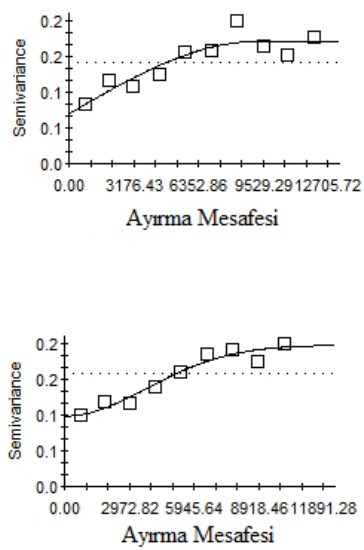

Ayrma Mesafesi
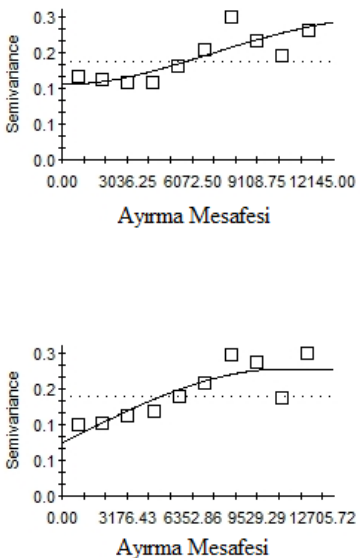

b)

$\mathrm{EC}(\mathrm{dS} / \mathrm{m}) \quad(0-30 \mathrm{~cm})$

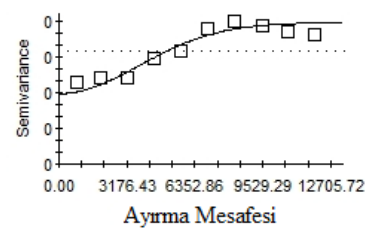

$\mathrm{EC}(\mathrm{dS} / \mathrm{m})(30-60 \mathrm{~cm})$

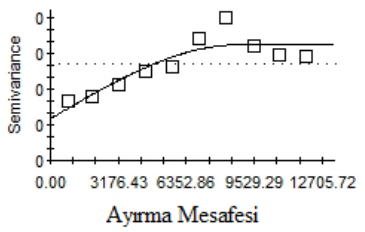

$\mathrm{EC}(\mathrm{dS} / \mathrm{m})(60-90 \mathrm{~cm})$

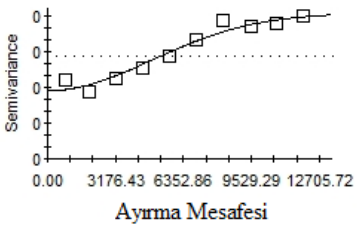

$\mathrm{EC}(\mathrm{dS} / \mathrm{m}) \quad(90-120 \mathrm{~cm})$

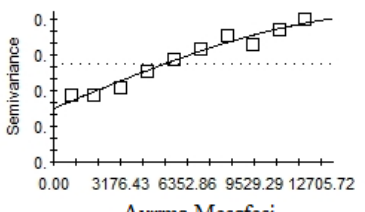

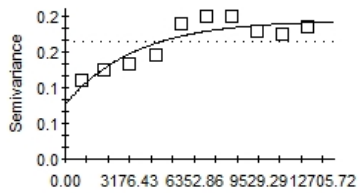

Ayrma Mesafesi
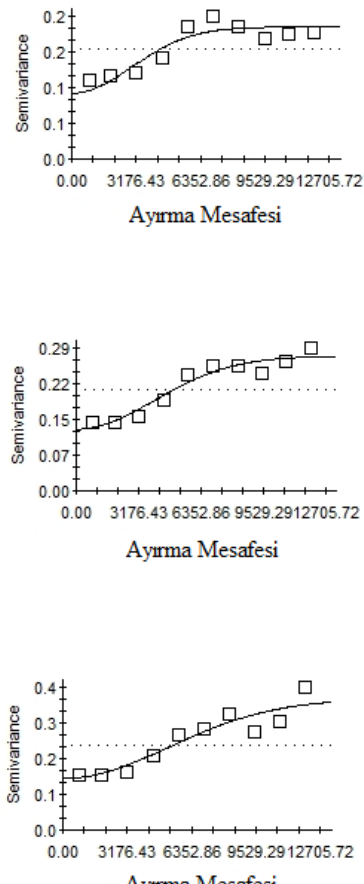

Şekil 2. Toprakların EC özelliklerine ait semivariogram modelleri a) 2010 sulama öncesi, b) 2016 sulama öncesi, c) 2016 sulama sonrası 


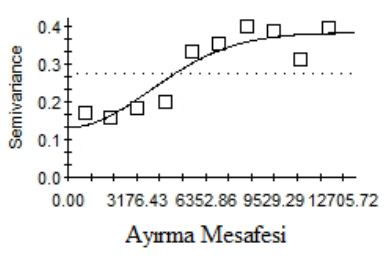

Ayrma Mesafes
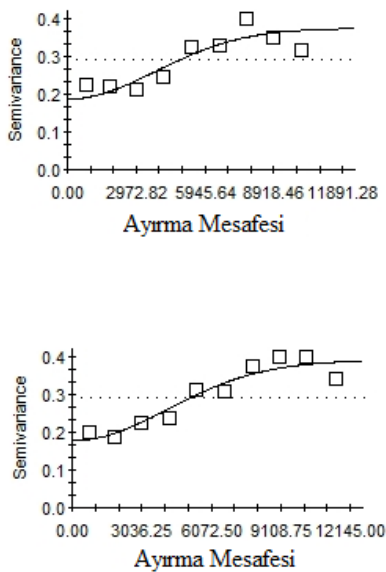

Ayırma Mesafesi

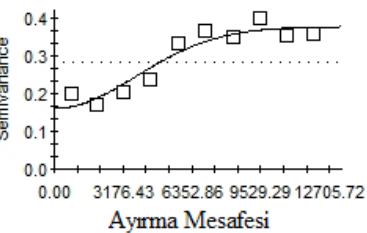

b)

$\operatorname{ESP}(\%)(0-30 \mathrm{~cm})$

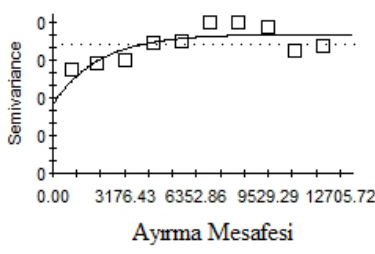

$\operatorname{ESP}(\%)(30-60 \mathrm{~cm})$

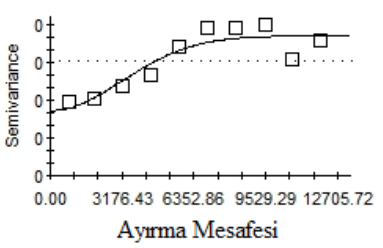

$\operatorname{ESP}(\%)(60-90 \mathrm{~cm})$

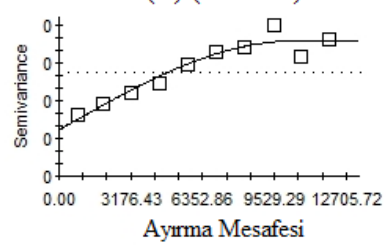

$\operatorname{ESP}(\%)(90-120 \mathrm{~cm})$

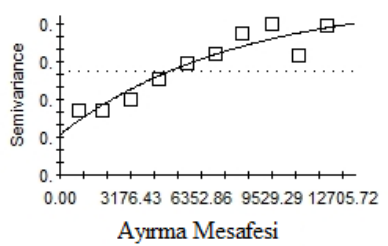

c)
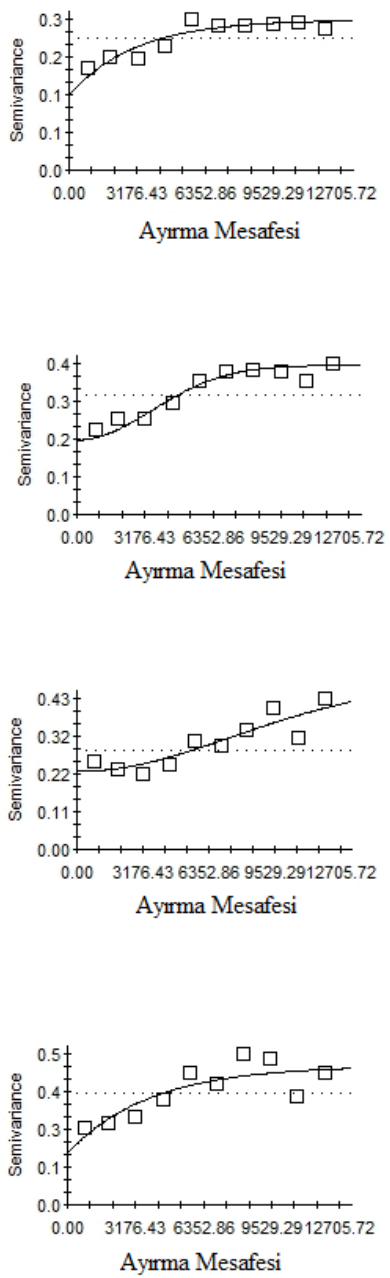

Şekil 3. Toprakların ESP özelliklerine ait semivariogram modelleri a) 2010 sulama öncesi, b) 2016 sulama öncesi, c) 2016 sulama sonras1

Jeoistatistik analiz sonucunda belirlenen en uygun modeller kullanılarak çalışma alanı topraklarının EC ve ESP değerlerine ait her üç dönemde ve dört farklı derinlikte alansal dă̆ılım haritaları sırasıyla Sekil 4 ve Şekil 5'de verilmiştir. Alansal dağılım haritaları incelendiğinde toprak tuzluluğu ve sodikliği genellikle çalışma alanının doğu ve kuzeydoğusunda diğer alanlara göre daha yüksek bulunmuştur. Toprakların EC değerlerinin her üç dönemde de derinlikle birlikte azaldığı görülmektedir (Şekil 4). Bunun sebebi derinlikle birlikte kil fraksiyonlarının azalması ve kum ile silt fraksiyonlarına bağlı olarak alt katmanlarda EC'yi yükseltecek kimyasal özelliklerin azalmasına ve ayrica bu katmanlarda yıkama durumlarının daha yüksek olmasına bağlanabilir (Taşan, 2017). 2010 yılı sulama öncesi dönemde EC ve ESP değerlerinin 2016 yılına göre daha yüksek olduğu belirlenmiştir. 2010 yılında çalışma alanının büyük bölümünde sodik ve çok sodik özellik gösteren alanların olduğu belirlenmiştir. Sodikliğin çalışma alanının doğusuna doğru artış gösterdiği ve genel olarak alt katmanlara doğru gidildikçe sodiklik sorununda artış olduğu belirlenmiştir. Sulama suyunun elektrolit konsantrasyonu ve toprakların değişebilir katyon bileşimi, sodyum tehlikesini belirleyen iki temel faktördür (Sposito, 2008; Güler ve ark., 2014). Güler ve ark., (2014) Bafra ovasında yaptıkları çalışmada toprakların EC, ESP ve $\mathrm{pH}$ değerlerinin çalışma alanının kuzeyinde ve doğusunda yüksek çıkmasının sebebini, bu kısımlarda yeraltı suyu seviyesinin yüksek olmasına bağlamışlardır. Ayrıca kötü kalitedeki suyun sulama amacıyla kullanılmasının EC, ESP ve pH değerlerinde artışa neden olabileceğini bildirmişlerdir. 

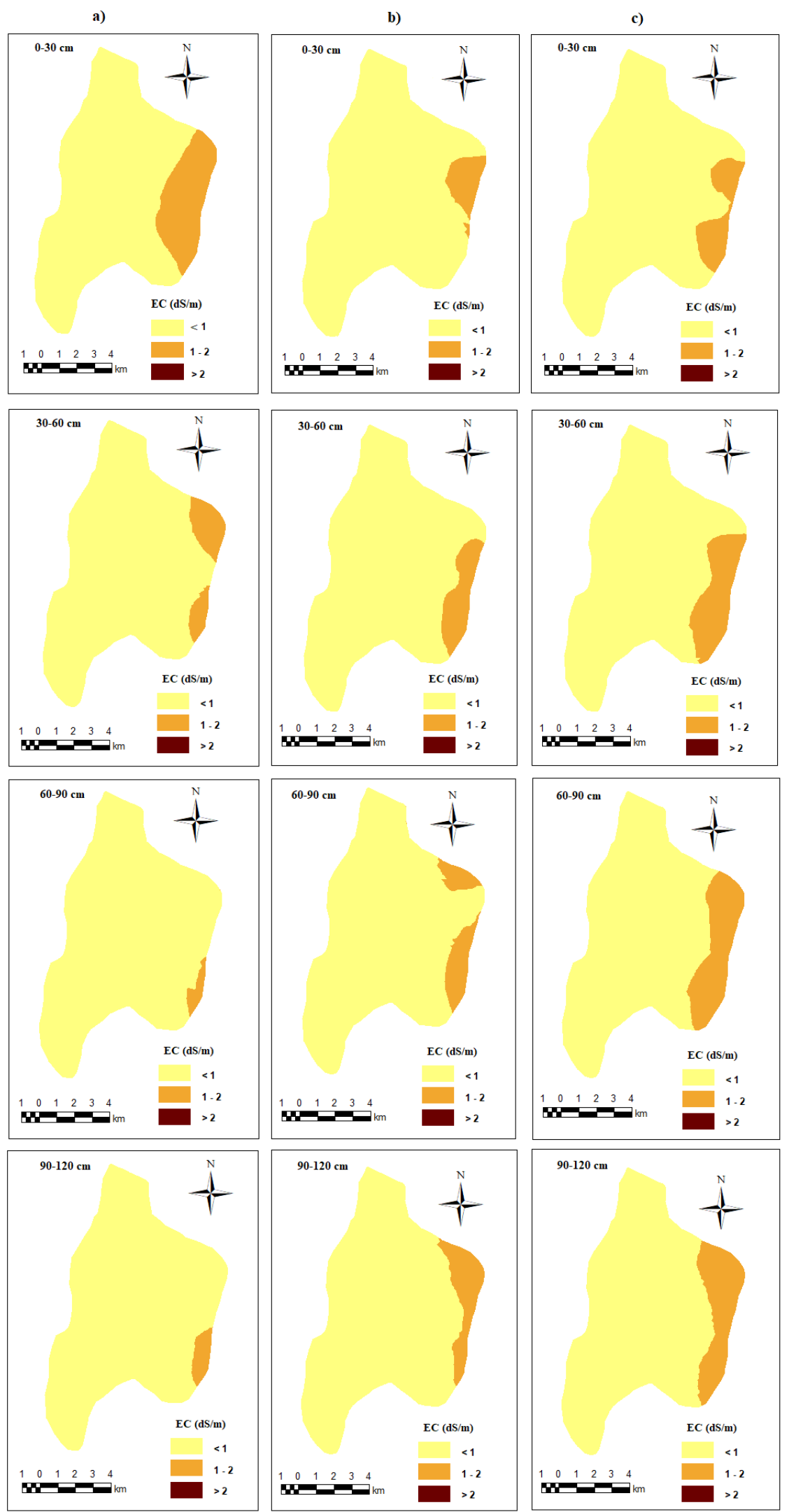

Şekil 4. EC dağılım haritaları a) 2010 sulama öncesi, b) 2016 sulama öncesi, c) 2016 sulama sonrası 

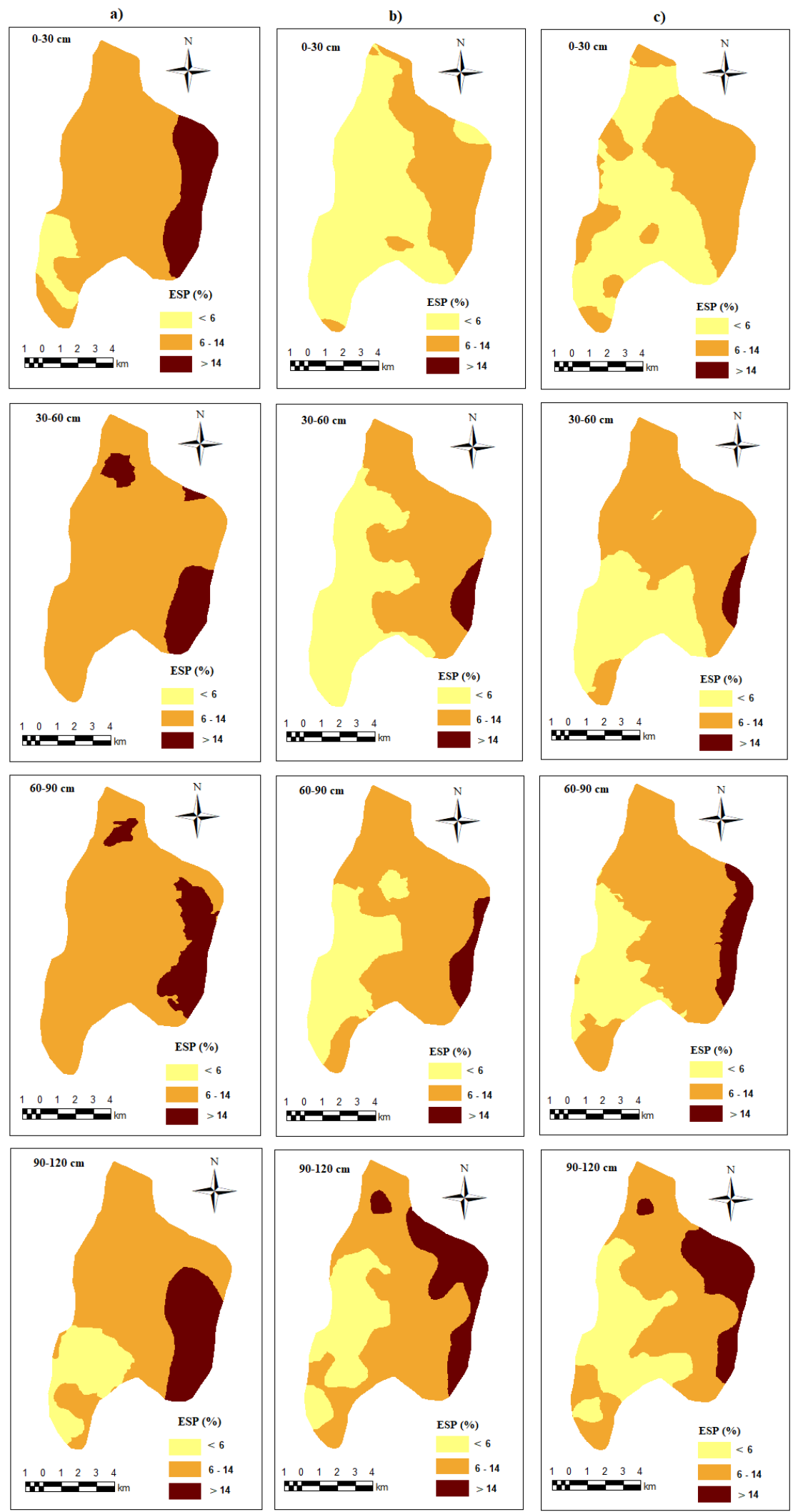

Şekil 5. ESP dağılım haritaları a) 2010 sulama öncesi, b) 2016 sulama öncesi, c) 2016 sulama sonrası 
Çalışma alanı toprakların tuzluluk ve sodiklik durumlarının belirlenmesi için hazırlanan alansal dağılım haritalarından hesaplanmış alanlar ve yüzdelik oranları ise Çizelge 4'de verilmiştir. Çalışma alanında toprakların elektriksel iletkenlik değeri için yapılan sınıflandırmaya göre tüm alanın EC değerinin her üç dönemde de $2 \mathrm{dS} \mathrm{m}^{-1}$ değerinden küçük olduğu belirlenmiştir. 2010 yılı sulama öncesi dönemde yüzey toprağının EC değeri, tüm alanın \% 16.7'sinde 1-2 dS $\mathrm{m}^{-1}$ aralığında olurken, 2016 yılı sulama öncesinde bu aralık alanın \% 5.2'sinde oluşmuş, 2016 yılı sulama sonrasına gelindiğinde ise bu katmanda bir miktar tuzluluk artı̧̧ı olmuş ve tüm alanın \% 20.8'inde EC değerleri 1-2 $\mathrm{dS} \mathrm{m}^{-1}$ arasında olmuştur. 2016 yılı sulama öncesi ve sulama sonrası dönemler karşılaştırıldığında tüm katmanlarda sulama sonrası dönemde EC değerinde artış olduğu belirlenmiştir.

Çizelge 4. Çalışma alanının tuzluluk ve sodiklik durumlarının alansal dağılımları

\begin{tabular}{|c|c|c|c|c|c|c|c|c|c|}
\hline & & \multicolumn{8}{|c|}{ Toprak derinliği } \\
\hline & & \multicolumn{2}{|c|}{$0-30 \mathrm{~cm}$} & \multicolumn{2}{|c|}{$30-60 \mathrm{~cm}$} & \multicolumn{2}{|c|}{$60-90 \mathrm{~cm}$} & \multicolumn{2}{|c|}{$90-120 \mathrm{~cm}$} \\
\hline & & \multicolumn{8}{|c|}{ EC sinıfi } \\
\hline \multirow{4}{*}{2010 Sulama Öncesi } & Aralığ $1(\mathrm{dS} / \mathrm{m})$ & Alan (ha) & $(\%)$ & Alan (ha) & $(\%)$ & Alan (ha) & $(\%)$ & Alan (ha) & $(\%)$ \\
\hline & $<1$ & 7852.8 & 83.3 & 8741.1 & 92.8 & 9269.5 & 98.4 & 9173.9 & 97.4 \\
\hline & $1-2$ & 1570.2 & 16.7 & 681.9 & 7.2 & 153.5 & 1.6 & 249.1 & 2.6 \\
\hline & $>2$ & 0 & 0 & 0 & 0 & 0 & 0 & 0 & 0 \\
\hline \multirow{3}{*}{2016 Sulama Öncesi } & $<1$ & 8937.3 & 94.8 & 8667.9 & 92.0 & 8699.1 & 92.3 & 8619.7 & 91.5 \\
\hline & $1-2$ & 485.7 & 5.2 & 755.1 & 8.0 & 723.9 & 7.7 & 803.3 & 8.5 \\
\hline & $>2$ & 0 & 0 & 0 & 0 & 0 & 0 & 0 & 0 \\
\hline \multirow{4}{*}{2016 Sulama Sonrası } & $<1$ & 7465.8 & 79.2 & 8225.8 & 87.3 & 7994.5 & 84.8 & 8098.9 & 85.9 \\
\hline & $1-2$ & 1957.2 & 20.8 & 1197.2 & 12.7 & 1428.5 & 15.2 & 1324.1 & 14.1 \\
\hline & $>2$ & 0 & 0 & 0 & 0 & 0 & 0 & 0 & 0 \\
\hline & & \multicolumn{8}{|c|}{ ESP sinifi } \\
\hline \multirow{4}{*}{2010 Sulama Öncesi } & Aralığ $1(\%)$ & Alan (ha) & $(\%)$ & Alan (ha) & $(\%)$ & Alan (ha) & $(\%)$ & Alan (ha) & $(\%)$ \\
\hline & $<6$ & 741.7 & 7.9 & 0 & 0 & 0 & 0 & 1635.9 & 17.4 \\
\hline & $6-14$ & 7091.9 & 75.3 & 8189.5 & 86.9 & 7904.5 & 83.9 & 5997.7 & 63.6 \\
\hline & $>14$ & 1589.4 & 16.9 & 1233.5 & 13.1 & 1518.5 & 16.1 & 1789.4 & 19.0 \\
\hline \multirow{3}{*}{2016 Sulama Öncesi } & $<6$ & 6321.4 & 67.1 & 3956.1 & 42.0 & 2806.2 & 29.8 & 2274.2 & 24.1 \\
\hline & $6-14$ & 3101.6 & 32.9 & 5092.6 & 54.0 & 6100.3 & 64.7 & 5415.5 & 57.5 \\
\hline & $>14$ & 0 & 0 & 374.3 & 4.0 & 516.6 & 5.5 & 1733.3 & 18.4 \\
\hline \multirow{3}{*}{2016 Sulama Sonrası } & $<6$ & 4961.2 & 52.6 & 3298.7 & 35.0 & 2356.0 & 25.0 & 3291.2 & 34.9 \\
\hline & $6-14$ & 4461.8 & 47.4 & 5853.6 & 62.1 & 6282.2 & 66.7 & 4616.5 & 49.0 \\
\hline & $>14$ & 0.0 & 0.0 & 270.6 & 2.9 & 784.9 & 8.3 & 1515.3 & 16.1 \\
\hline
\end{tabular}

Toprakların ESP değeri arazilerde sodikleşme sorununun belirlenmesinde kullanılan bir özelliktir. Arazilerde ESP değeri arttıkça topraklarda sodiklik sorunu artmaktadır. Toprakların ESP değerinin 6.0'dan yüksek olması sodyum açısından sorun oluşturabileceği anlamına gelmektedir. ESP değerinin $6.0^{\prime}$ dan düşük olmas1 sodik olmayan toprak, 6.0 ile 14.0 arasinda olması az sodik toprak ve 14.0 'den büyük olması ise çok sodik toprak olarak sınıflandırılmaktadır (Hazelton ve Murphy, 2016). Buna göre 2010 yılında çalışma alanının büyük bölümünde (yaklaşık \% 92) orta ve yüksek düzeyde sodik toprakların olduğu belirlenmiștir. Yüzey katmanında sodik toprakların varlığ $\% 16.9$ olarak belirlenmiş ve genel olarak derinlik arttıkça artış göstermiş, en alt katmanda ise tüm alanın \% 19'unda çok sodik topraklara rastlanmıştır. 2016 yılı sulama öncesi ve sonrası dönemde $0-30 \mathrm{~cm}$ toprak derinliğinde çok sodik özellikte topraklar bulunmazken, sulama öncesinde 3101.6 ha ve sulama sonrasinda 4461.8 ha alanda az sodik özellikte topraklara rastlanmıştır (Çizelge 4).
Yapılan değerlendirmeler doğrultusunda çalışma alanı topraklarında tuzluluk ve sodik özellik gösteren alanların varlığı, 2010 yılında, 2016 yılına göre daha yüksek bulunmuştur. Ayrıca 2016 yılı sulama öncesi ve sonrası dönemler karşılaştırıldığında ise sulama sonrası dönemde artış olduğu belirlenmiştir. Bafra ovası sağ sahil sulaması inşaasına 1993 yılında başlanmış ve 2014 yılı itibari ile sulama projesi tamamlanarak tüm alan sulamaya açılmıştır. 2010 yılından sonra artan sulama ve drenajın etkisiyle tuzlu ve sodik topraklarda önemli oranda azalma meydana gelmiştir. Bunun yanı sıra sulama sonrası dönemde sulama öncesine göre tuzluluk değerlerinin yükselmesi tuz içeren gübre kullanımına ve sulama suyunun değişen miktar ve kalitesine bağlanmıştır. Yapılan çeşitli çalışmalarda bir sulama alanında sulama mevsimi boyunca toprakta tuz içeriğinin artabileceği ve kış periyodunda ise yağışların yıkama etkisi ile azalabileceği ifade edilmiştir (Yurtseven ve Güngör, 1990; Yurtseven ve Sönmez, 1996; Yurtseven ve ark., 2012). 


\section{Sonuç}

Sulu tarım alanlarında sürdürülebilirliği etkileyen durumlar, sulama sistemlerinin işletilmesi, uygun sulama yönetiminin seçilmesi, sulama suyu kalitesine bağlı olarak tuzlulaşma problemleri, taban suyu ve drenajın yönetilmesi olarak sıralanabilir. Bu çalıșma Bafra ovası sağ sahil sulama alanındaki topraklarının mevcut EC ve ESP özelliklerinin uzaysal değișkenliğini ortaya koymuştur. Toprakların EC ve ESP değerleri tüm derinliklerde ve tüm dönemlerde yüksek değişkenlik göstermiştir. Ayrıca çalışma alanı topraklarının EC ve ESP özellikleri orta derecede alansal bağımlılık göstermiştir. Çalışma alanında en düşük değişkenlik gösteren özellik pH iken, toprakların kum, kil ve $\mathrm{CaCO}_{3}$ içerikleri ise yüksek derecede değişkenlik göstermiştir. Kum ve kil içeriğinin yüksek değişkenlik göstermesi, çalışma alanında alüvyal ana materyalin farklılık göstermesine ve çalışma alanının geniş olmasına bağlanmıştır. Çalışma kapsamında incelenen tüm parametreler için jeoistatistiksel etki uzaklığı 3100 m'den büyük bulunmuştur. Çalışma alanı topraklarının EC ve ESP'sinin alansal dağılımı 2010 yılından 2016 yılına kadar önemli derecede değişmiştir. Ayrıca sulamanın toprak özelliklerine olası etkilerini belirlemek amaciyla 2016 yılı sulama öncesi ve sonrası dönemlerde alınan toprakların EC ve ESP'leri araştırılmıştır. 2016 yılı sulama öncesi dönemde ortalama EC değeri $0.63 \mathrm{dS} \mathrm{m}^{-1}$ iken, sulamalar ile bir miktar tuz birikimi olmuş ve 2016 yılı sulama sonrasında EC değerleri artarak ortalama $0.74 \mathrm{dS} \mathrm{m}$ olmuştur. EC değerleri genel olarak derinlikle birlikte azalmıştır. Tüm dönemler birlikte değerlendirildiğinde çalışma alanı topraklarında tuzluluk sorunu olmadığı belirlenmiştir. Ancak en yüksek EC değerleri arasında 2010 y1lında $4.30 \mathrm{dS} \mathrm{m}^{-1}, 2016$ yilı sulama öncesinde $6.31 \mathrm{dS} \mathrm{m}^{-1}$ ve 2016 y1l sulama sonrasinda $5.77 \mathrm{dS} \mathrm{m}^{-1}$ değerlerinin bulunması ovada yer yer tuzluluk probleminin olduğuna ve riskli alanların varlığına işaret etmektedir. Bu bağlamda çalışma alanının doğusunda tuzluluğun yüksek olduğu alanlar ile sodik alanların varlığı belirlenmiştir. Bu alanlarda sulama mevsiminde buharlaşma ile çözünebilir tuzların yukarı taşınmasının takibi için yeraltı suyu tuzluluğu ve derinliğinin düzenli olarak izlenmesi önerilmektedir. Toprak özelliklerinin alansal bağımlılığının bilinmesi önemlidir. Böylelikle güçlü alansal bağımlılığa sahip yönetim parametrelerinin daha kolay yönetilmesine ve alana özgü doğrulukta hassas önlemlerin alınabilmesine olanak sağlayacaktır.

\section{Teşekkür}

$\mathrm{Bu}$ çalışma, TÜBİTAK (1001) tarafindan 1160715 numaralı proje olarak desteklenen doktora tezinin bir bölümüdür. Katkılarından dolayı TÜBİTAK'a teşekkür ederiz.

\section{Kaynaklar}

Abrol, I. P., Yadav, J. S. P., Massoud, F. I., 1988. Saltaffected soils and their management (FAO Soil Bulletin, vol. 39). Food and Agriculture Organization of the United Nations, Rome.

Abrol, I.P., Chhabra, R., Gupta, P.K., 1980. A fresh look at the diagnostic criteria for sodic soils. I. International Symposium on Salt Affected Soils. 142-147, Feb. 18-21, Central Soil Salinity Reserch Institute, Karnal.

Ahmad, S., Ghafoor, A., Qadir, M., Aziz, M.A., 2011. Amelioration of a calcareous saline-sodic soil by gypsum application and different crop rotations. International Journal of Agriculture \& Biology. 8(2):142-146.

Akbaş, F., 2011. Tokat Kazova topraklarinin yarayişli fosfor düzeyinin jeoistatistik tahmin ve simulasyon metodlarıyla modellenmesi ve haritalanması. Tarım Bilimleri Dergisi, 18: 63-76.

Akramkhanov, A., Brus, D., Walvoort, D., 2014. Geostatistical monitoring of soil salinity in Uzbekistan by repeated EMI surveys. Geoderma, 213:600-607.

Allbed, A., Kumar, L., 2013. Soil salinity mapping and monitoring in arid and semi-arid regions using remote sensing technology: a review. Advances in remote sensing, 2(04): 373 .

Ardahanlioglu, O., Oztas, T., Evren, S., Yilmaz, H., Yildirim, Z. N., 2003. Spatial variability of exchangeable sodium, electrical conductivity, soil $\mathrm{pH}$ and boron content in salt-and sodium-affected areas of the Igdir plain (Turkey). Journal of Arid Environments, 54(3): 495-503.

Başbozkurt, H., Öztaş, T., Karaibrahimoğlu, A., Gündoğan, R., Genç, A., 2013. Toprak özelliklerinin mekansal değişim desenlerinin jeoistatistiksel yöntemlerle belirlenmesi. Atatürk Üniversitesi Ziraat Fakültesi Dergisi, 44(2):169-181.

Batarseh, M., 2017. Sustainable Management of Calcareous Saline-Sodic Soil in Arid Environments: The Leaching Process in the Jordan Valley. Applied and Environmental Soil Science, Volume 2017, Article ID 1092838:1-9.

Bhargava, G.P., Abrol, I.P., 1978. Characteristics of some typical salt-affected soils of Uttar Pradesh. Report No. 6. Central Soil Salinity Research Institute, Karnal.

Bilgili, A. V., 2013. Spatial assessment of soil salinity in the Harran Plain using multiple kriging techniques. Environmental monitoring and assessment, 185(1): 777-795.

Bouyoucos G. J., 1951. A recalibration of the hydrometer method for making mechanical analysis of the soils. Agronomy Iournal, 43(9): 343-348.

Büyükgüner, E., 2007. Farklı kullanım altındaki toprakların fiziksel ve kimyasal özelliklerinin incelenmesi. Gaziosmanpaşa Üniversitesi, Fen Bilimleri Enstitüsü, Yüksek Lisans Tezi, 76. 
Cambardella, C., Moorman, T., Parkin, T., Karlen, D., Novak, J., Turco, R., Konopka, A., 1994. Field-scale variability of soil properties in central Iowa soils. Soil Science Society of America Journal, 58(5): 1501-1511.

Cemek, B., GüLer, M., Kiliç, K., Demir, Y., Arslan, H., 2007. Assessment of spatial variability in some soil properties as related to soil salinity and alkalinity in Bafra plain in northern Turkey. Environmental monitoring and assessment, 124(1-3): 223-234.

Dai, F., Zhou, Q., Lv, Z., Wang, X., Liu, G., 2014. Spatial prediction of soil organic matter content integrating artificial neural network and ordinary kriging in Tibetan Plateau. Ecological Indicators, 45: 184-194.

Dinh, Q. T., Liang, D., Thi Anh Thu, T., Le, T. D. H., Dinh Vuong, N., Pham, V. T., 2018. Spatial prediction of saline and sodic soils in rice-shrimp farming land by using integrated artificial neural network/regression model and kriging. Archives of Agronomy and Soil Science, 64(3): 371-383.

Elbashier, M. M., Xiaohou, S., Ali, A. A., Osman, B. H., 2016. Modeling of Soil Exchangeable Sodium Percentage Function to Soil Adsorption Ratio on Sandy Clay Loam Soil, International Journal of Plant \& Soil Science. 10(5): 1-6.

Emadi, M., Baghernejad, M., 2014. Comparison of spatial interpolation techniques for mapping soil $\mathrm{pH}$ and salinity in agricultural coastal areas, northern Iran. Archives of Agronomy and Soil Science, 60(9),:1315-1327.

Emadi, M., Baghernejad, M., Maftoun, M., 2008. Assessment of some soil properties by spatial variability in saline and sodic soils in Arsanjan plain, Southern Iran. Pakistan journal of biological sciences: PJBS, 11(2):238-243.

Gee, G. W., Bauder J.W., 1986. Particle-Size Analysis. In: Klute, A., Ed., Methods of Soil Analysis, Part 1. Physical and Mineralogical Methods, Agronomy Monograph No. 9, 2nd Edition, American Society of Agronomy/Soil Science Society of America, Madison, WI, 383-411.

Goovaerts, P., 1998. Geostatistical tools for characterizing the spatial variability of microbiological and physico-chemical soil properties. Biology and Fertility of soils, 27(4): 315334.

Güler, M., Arslan, H., Cemek, B., Erşahin, S., 2014. Long-term changes in spatial variation of soil electrical conductivity and exchangeable sodium percentage in irrigated mesic ustifluvents. Agricultural Water Management, 135: 1-8.

Gupta, R.K., Bhumbla, D.K. and Abrol, I.P., 1983. Sodium-calcium exchange equilibria in soils as affected by calcium carbonate and organic matter. Soil Sci. (in press).

Gupta, R.K., Chabbra, R. and Abrol, I.P., 1982. Fluorine adsorption behaviour in alkali soils: relative roles of pH and sodicity. Soil Sci., 133: 364-368.
Hazelton, P., Murphy, B., 2016. Interpreting soil test results: What do all the numbers mean? : CSIRO publishing.

Joseph, E.A., 2016. Rice cultivation in saline tracts of Kerala: an overview. Int J Fish Aquat Stud. 4:355358.

Journel, A.G., Huijbregts, C.J., 1978. Mining geostatistics (Vol. 600): Academic press London.

Juan, P., Mateu, J., Jordan, M., Mataix-Solera, J., Meléndez-Pastor, I., Navarro-Pedreño, J., 2011. Geostatistical methods to identify and map spatial variations of soil salinity. Journal of Geochemical Exploration, 108(1),:62-72.

Kacar, B., 1994. Bitki ve toprağın kimyasal analizleri. 3: Toprak Analizleri Ankara Üniversitesi Ziraat Fakültesi Eğitim Araştırma ve Geliştirme Vakfı Yayınları No: 3. In: Ankara.

Kılıç, K., Kılıç, S., 2007. Spatial variability of salinity and alkalinity of a field having salination risk in semi-arid climate in northern Turkey. Environmental monitoring and assessment, 127(1-3): 55-65.

Li, X.-b., Kang, Y.-h., Wan, S.-q., Chen, X.-1., Chu, L.1., Xu, J.-c., 2015. First and second-year assessments of the rapid reconstruction and re-vegetation method for reclaiming two saline-sodic, coastal soils with drip-irrigation. Ecological Engineering, 84: 496-505.

Liu, G., Li, J., Zhang, X., Wang, X., Lv, Z., Yang, J., Shao, H., Yu, S., 2016. GIS-mapping spatial distribution of soil salinity for Eco-restoring the Yellow River Delta in combination with Electromagnetic Induction. Ecological Engineering, 94: 306-314.

Malicki, M., Walczak, R., 1999. Evaluating soil salinity status from bulk electrical conductivity and permittivity. European journal of soil science, 50(3), 505-514.

Moasheri, S. A., Foroughifar, H., 2013. Estimation of the values of soil absorption ratio using integrated geostatistical and artificial neural network methods. International Journal of Agriculture and Crop Sciences (IJACS), 5(20): 2423-2433.

Poshtmasari, H. K., Sarvestani, Z. T., Kamkar, B., Shataei, S., Sadeghi, S., 2012. Comparison of interpolation methods for estimating $\mathrm{pH}$ and $\mathrm{EC}$ in agricultural fields of Golestan province (north of Iran). International Journal of Agriculture and Crop Sciences, 4(4): 157-167.

Rhoades, J. and Chanduvi, F., 1999. Soil salinity assessment: Methods and interpretation of electrical conductivity measurements (Vol. 57): Food and Agriculture Org.

Richards, L., 1954. Diagnosis and improvement of saline and alkali soils. Handbook No. 60. US Department of Agriculture, Washington, DC.

Rodrigues, M. S., Alves, D. C., Cunha, J. C., Lima, A. M. N., Cavalcante, I. H. L., da Silva, K. A., de Melo Junior, J. C. F., 2018. Spatial analysis of soil salinity in a mango irrigated area in semi-arid climate 
region. Australian Journal of Crop Science, $12(8),: 1288$.

Scudiero, E., Skaggs, T. H., Corwin, D. L., 2017. Simplifying field-scale assessment of spatiotemporal changes of soil salinity. Science of the Total Environment, 587: 273-281.

Shahabi, M., Jafarzadeh, A. A., Neyshabouri, M. R., Ghorbani, M. A., Valizadeh Kamran, K., 2017. Spatial modeling of soil salinity using multiple linear regression, ordinary kriging and artificial neural network methods. Archives of Agronomy and Soil Science, 63(2): 151-160.

Sposito, G., 2008. The Chemistry of Soils. 2nd Edition, Oxford University Press, New York..

Taşan, M., 2017. Samsun İli Alaçam İlçesi Kıyı Bölgesi Çeltik Alanlarının Sulanmasında Yeraltı Suyu Kullanımının Toprak-Su Özellikleri ve Deniz Suyu Girișimine Etkilerinin Farklı Enterpolasyon Yöntemleri ile Değerlendirilmesi. Ondokuz Mayıs Üniversitesi Fen Bilimleri Enstitüsü, Doktora Tezi, 267.

Taşan, S., 2018. Bafra ovası sağ sahil topraklarının sulama açısından bazı fiziksel ve kimyasal özelliklerindeki değişimin modeller ile tahmini. Ondokuz Mayıs Üniversitesi, Fen Bilimleri Enstitüsü, Doktora Tezi, 346.

Taşova, H., Akın, A., 2013. Marmara Bölgesi topraklarının bitki besin maddesi kapsamlarının belirlenmesi, veri tabanının oluşturulması ve haritalanması. Toprak Su Dergisi, 2(2): 83-95.

Tekin, A. B., Gunal, H., Sindir, K., Balci, Y., 2011. Spatial structure of available micronutrient contents and their relationships with other soil characteristics and corn yield. Fresenius Environmental Bulletin, 20(3),:783-792.

Trangmar, B. B., Yost, R. S., Uehara, G., 1986. Application of geostatistics to spatial studies of soil properties." Advances in agronomy. Vol. 38. Academic Press, 45-94.

Webster, R., 2001. Statistics to support soil research and their presentation. European journal of soil science, 52(2): 331-340.

Webster, R., Oliver, M. A., 2001. Geostatistics for environmental scientists (Statistics in Practice).

Wichelns, D., Qadir, M., 2015. Achieving sustainable irrigation requires effective management of salts, soil salinity, and shallow groundwater. Agricultural Water Management, 157: 31-38.

Wilding, L. P., 1985. Spatial Variability: Its Documentation, Accommodation, and Implication to Soil Surveys. In Soil spatial Variability. D. R. Nielsen and J. Bouma (eds). Pudoc, Wageningen, The Netherlands, 166- 194.

Yurtseven, E., Güngör, Y., 1990. Değişik Tuzluluk Düzeylerindeki Sulama Sularının Toprak Tuzlulaşmasına Etkisi. Doğa Tr. J. Of Agriculture and Forestry, 14: 555-561.

Yurtseven, E., Öztürk, H.S., Avc1, S., Altınok, S., Selenay, M.F., 2012. Farklı Sulama suyu kalitesi ve yıkama oranı uygulamalarında profil tuzluluğunun değişimi. Toprak Su Dergisi, 1(1).

Yurtseven, E., Sönmez, B., 1996. Sulama suyu tuzluluğunun domates verimine ve toprak tuzluluğuna etkisi. Tr. J. of Agriculture and Forestry, 20(1): 27-33.

Zare-Mehrjardi, M., Taghizadeh-Mehrjardi, R., Akbarzadeh, A., 2010. Evaluation of geostatistical techniques for mapping spatial distribution of soil $\mathrm{pH}$, salinity and plant cover affected by environmental factors in Southern Iran. Not Sci Biol. 2:92-103.

Zhang, X.-Y., Yue-Yu, S., Zhang, X.-D., Kai, M., Herbert, S., 2007. Spatial variability of nutrient properties in black soil of northeast China. Pedosphere, 17(1):19-29. 